Revista Brasileira de Ensino de Física, v. 26, n. 4, 291, (2004)

www.sbfisica.org.br

\title{
Editorial
}

\section{O ano mundial da Física e o Edson}

Com orgulho anunciamos que o primeiro número de $R B E F$ de 2005 trará a tradução de alguns artigos fundamentais de Einstein sobre:

- Teoria quântica do calor específico: o nascimento da Física Moderna do Estado Sólido (1907)

- Revisão da Relatividade Restrita e as primeiras idéias acerca da Relatividade Geral (1907)

- Dualidade onda-partícula da radiação eletromagnética (1909)

- Emissão e absorção da radiação: princípios básicos do laser (1917)

- Invariância do espaço de fase e a Teoria de Sistemas Caóticos (1917)

- Condensação de Bose-Einstein (1925)

Além desses trabalhos, artigos convidados tratarão de uma introdução à Relatividade Geral.

Outro fato digno de atenção é o primeiro artigo deste número. Enviado pela Secretaria de Estado de Esportes do Rio de Janeiro ao personagem que inspirou os autores a escrevê-lo, recebeu do mesmo a seguinte carta em resposta:

"Gostaria de informar que fiquei muito lisonjeado com o trabalho desenvolvido pelos professores Carlos Eduardo Aguiar e Gustavo Rubini.

Para ser bem sincero, conheço muito pouco sobre "forças aerodinâmicas", porém lendo a introdução do trabalho, pude entender um pouquinho sobre o assunto.

Fiquei feliz por ter sido escolhido, um jogo de futebol na Copa de 70 contra a Tchecoslováquia, o gol que não foi feito e que até hoje é discutido em todo o mundo, mais do que muitos gols que fiz na Copa 70.

Gostaria que o senhor [Secretário de Esportes] fosse portador de meus agradecimentos aos professores Carlos Eduardo Aguiar e Gustavo Rubini de tão importante trabalho para o desenvolvimento da Ciência e Tecnologia.

Receba um grande abraço de minha parte."

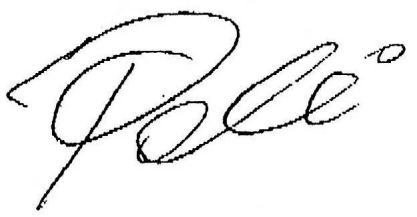

Copyright by the Sociedade Brasileira de Física. Printed in Brazil. 